\title{
Isoflurane Preconditioning Promotes the Survival and Migration of Bone Marrow Stromal Cells
}

\author{
Yu Sun Qi-fang Li Jia Yan Rong Hu Hong Jiang \\ Department of Anesthesiology, Ninth People's Hospital Affiliated to Shanghai Jiao Tong University \\ School of Medicine, Shanghai, China
}

\section{Key Words}

Isoflurane $\bullet$ Bone marrow stromal cells (BMSCs) • CXCR4 • Hypoxia-inducible factor- 1 (HIF-1 $\alpha$ ) - Akt • Survival • Migration • Ischemia

\begin{abstract}
Background: Preconditioning with the volatile anesthetic isoflurane exerts protective effects in animal models of ischemia. The cytoprotective effects of isoflurane are dependent on the expression of hypoxia inducible factor-1 (HIF-1), a dimeric transcription factor that mediates cellular responses to hypoxia. Methods: We investigated the effect of isoflurane preconditioning on bone marrow stromal cell (BMSC) survival and function. Results: Short exposures to low isoflurane concentrations promoted in vitro survival and migration of BMSCs, whereas long exposures and high doses had the opposite effect. At specific doses and times, isoflurane upregulated the expression of HIF-1 $\alpha$ and the stromal-derived factor-1 receptor CXCR4, and induced the activation of Akt, similar to hypoxia, and the effect of isoflurane was abrogated by silencing of HIF-1 $\alpha$ or inhibition of PI3K/Akt signaling. In vivo experiments showed that isoflurane preconditioning increased the engraftment of BMSCs into the ischemic brain and improved functional recovery in a mouse model of stroke. Conclusion: Isoflurane preconditioning at specific doses and times improves the survival and function of BMSCs through the upregulation of CXCR4 via a mechanism involving HIF-1 $\alpha$ expression and the PI3K/Akt pathway, suggesting that anesthetic preconditioning could be developed as a strategy to improve the efficiency of cell therapy.

Copyright (C) 2015 S. Karger AG, Basel
\end{abstract}

\section{Introduction}

Isoflurane is a potent volatile anesthetic agent commonly used in clinical practice. Isoflurane has both anti-apoptotic and pro-apoptotic effects under different conditions [1]. It is cytotoxic in a concentration and time-dependent manner in vitro, inducing neuronal

Hong Jiang,

KARGER 125
Department of Anesthesiology, Ninth People's Hospital Affiliated to Shanghai Jiao Tong University School of Medicine. 639 Zhi Zao Ju Road, Shanghai, 200011 (China)

Tel. +86-21- 23271699, E-Mail dr_jianghong@163.com 
apoptosis in the developing brain and impairing memory and learning ability in rodents at clinically relevant concentrations [2-5]. However, isoflurane inhibits apoptosis in cardiac myocytes and protects the brain against ischemic injury [6,7]. Isoflurane preconditioning protects against reperfusion injury after myocardial ischemia in vitro and in vivo $[8,9]$. However, the mechanisms underlying the different effects of isoflurane remain unclear.

Isoflurane confers cytoprotection in a hypoxia inducible factor-1 (HIF-1) dependent manner [10]. HIF-1 is a dimeric transcription factor that mediates cellular responses to hypoxia. It is composed of a constitutively expressed HIF-1 $\beta$ subunit and an oxygen sensing HIF- $1 \alpha$ subunit, and their dimerization and translocation to the nucleus modulates the expression of many downstream genes [11]. Isoflurane upregulates the expression of HIF$1 \alpha$ in hepatoma cells, in the rat heart, neurons and in the kidney [9, 12-15]. Furthermore, isoflurane modulates the expression of HIF-1 responsive genes such as heme oxygenase 1, inducible nitric oxide synthase (iNOS) and vascular endothelial growth factor, rendering cells more tolerant to injury or stress [12]. The effect of isoflurane on the induction of HIF$1 \alpha$ expression was shown to be mediated by the activation of the Akt-mTOR and Akt-GSK $3 \beta$ pathways $[9,16]$.

Bone marrow stromal cells (BMSCs), also termed mesenchymal stem cells (MSCs), are precursors of non-hematopoietic tissues that have attracted attention because of their capacity for self-renewal, differentiation potential and possible use for cell and gene therapy [17]. Injection of BMSCs leads to their migration to the sites of injury and improves neurological function in a rat model of stroke $[17,18]$. However, the regenerative potential of BMSC transplantation depends on cell survival or the number of engrafted cells, and on the efficiency and specificity of their migration to the target areas or organs [19]. Stromal cell-derived factor-1 (SDF-1) plays important roles through the activation of a $\mathrm{G}$ proteincoupled receptor, CXCR4 [20]. Bone marrow stromal cells express SDF-1, which supports their survival and proliferation [21]. SDF-1 is upregulated at sites of injury and recruits CXCR4-expressing stem cells, which function in tissue repair, and delivery of SDF-1 into injured tissue promotes the recruitment of circulating stromal cells [22,23].

In the present study, we investigated the effect of isoflurane preconditioning on BMSC viability and function and examined the role of HIF- $1 \alpha$ and the phosphatidylinositol 3-kinase (PI3K)/Akt pathway in this process. Our results showed that short exposure to low-dose isoflurane promoted the survival and migration of BMSCs, upregulated the expression of CXCR4 and HIF- $1 \alpha$, activated Akt in vitro, and improved BMSC engraftment and functional recovery in a mouse model of stroke. Taken together, our results revealed a potential mechanism underlying the beneficial effects of isoflurane preconditioning for the improvement of neurological function after stroke and highlighted the time and dose dependency of anesthetic induced protection in the brain.

\section{Materials and Methods}

Isolation and culture of BMSCs

BMSCs were isolated from the bone marrow of rats as described previously [24]. After execution, bilateral femurs and tibiae were excised and immersed in 75\% alcohol for $3 \mathrm{~min}$, washed with PBS and the bone marrow was washed with Dulbecco's modified Eagle's medium (DMEM)/F12 supplemented with $10 \%$ FBS and $1 \%$ penicillin-streptomycin. The washing solution was placed in a cell culture flask in a $95 \%$ air $/ 5 \% \mathrm{CO}_{2}$ incubator at $37^{\circ} \mathrm{C}$. After $48 \mathrm{~h}$, the culture medium was replaced by medium with 5-bromo-2'deoxyuridine (BrdU, Sigma-Aldrich, St. Louis, MO) to identify BMSCs. To determine the identity of BMSCs, cells at passage 2 were incubated with fluorescence-conjugated antibodies against CD90, CD29 (expressed in BMSCs) and CD45 (not expressed in BMSCs) (BD Pharmingen, San Diego, CA, USA) at $4^{\circ} \mathrm{C}$ for $30 \mathrm{~min}$, washed in PBS and fixed with 4\% PFA for flow cytometry analysis.

Isoflurane preconditioning

Isoflurane preconditioning was performed as described previously [25]. Briefly, BMSCs were incubated at $37^{\circ} \mathrm{C}$ in a closed chamber in an atmosphere of $1 \%-10 \%$ isoflurane, $5 \% \mathrm{CO}_{2}, 20 \% \mathrm{O}_{2}$ and $\mathrm{N}_{2}$ for 


\section{Cellular Physiology Cell Physiol Biochem 2015;36:1331-1345 \begin{tabular}{l|l} 
and Biochemistry Publisned onIIne: July U1, 2015 & $\begin{array}{l}\text { C 2015 S. Karger AG, Basel } \\
\text { www.karger.com/cpb }\end{array}$ \\
\hline
\end{tabular} \\ Sun et al.: Isoflurane Promotes Survival and Function of BMSCs}

the indicated periods. And hypoxia-preconditioned BMSCs were cultured in a hypoxia chamber incubator at $37^{\circ} \mathrm{C}$, in $3 \% \mathrm{O}_{2}, 5 \% \mathrm{CO}_{2}$ and $92 \% \mathrm{~N}_{2}$ atmosphere for $24 \mathrm{~h}$. Control cells were treated in the same way without the addition of isoflurane.

\section{Cell proliferation assay}

Cell proliferation was measured with the 3-[4,5-dimethylthiazol-2-yl]-2,5-diphenyl tetrazolium bromide (MTT; Sigma) reagent, which was added to a final concentration of $0.2-0.5 \mathrm{mg} / \mathrm{mL}$ for $4 \mathrm{~h}$, after which the medium was aspirated and the resulting formazan precipitate was dissolved with dimethyl sulfoxide (DMSO). Absorbance was measured at $570 \mathrm{~nm}$ in a spectrophotometer and changes in absorbance, which reflected cell viability, were measured and expressed as a percentage of the controls.

\section{Cell apoptosis assay}

Apoptosis assays were performed using an Annexin V-fluorescein isothiocyanate (FITC) apoptosis detection kit (BD Pharmingen, San Diego, CA, USA) according to the manufacturer's instructions. Briefly, cells were resuspended in binding buffer containing Annexin VFITC and propidium iodide and incubated in the dark for 15 min. Cells were analyzed using a FACScan flow cytometer (BD Biosciences, San Jose, CA).

\section{In vitro cell migration assay}

BMSCs treated as indicated were seeded on $8 \mu \mathrm{m}$ pore polycarbonate membrane Boyden chamber inserts in a Transwell plate (Costar, Cambridge, MA) coated with Matrigel (BD Biosciences). DMEM containing $10 \%$ FBS was added to the lower chamber, incubated for $24 \mathrm{~h}$ at $37^{\circ} \mathrm{C}$ in a $5 \% \mathrm{CO}_{2}$ incubator, after which the cells on the top surface of the insert were removed with a cotton swab. Cells migrated to the bottom surface of the insert were fixed in $100 \%$ methanol for $2 \mathrm{~min}$, stained with hematoxylin and eosin (H\&E) and visualized by microscopy (400× magnification). The number of migrating cells was counted in five fields for each condition and represents the average of three independent experiments.

\section{Semiquantitative reverse transcription-polymerase chain reaction (RT-PCR)}

Total RNA was isolated from cells using the Trizol reagent (Invitrogen). Single-stranded cDNA was synthesized from $1 \mu \mathrm{g}$ of total RNA using a first-strand cDNA synthesis kit (Promega). PCR reactions were performed in a volume of $25 \mu \mathrm{L}$ containing $1 \mu \mathrm{L}$ cDNA, $2.5 \mathrm{mM} \mathrm{MgCl}{ }_{2}, 0.25 \mathrm{mM}$ dNTP, $1 \times$ PCR buffer, $1 \mu \mathrm{L}$ of each specific primer and $0.4 \mu \mathrm{L}(2 \mathrm{U})$ Taq DNA polymerase. The relative purity of the isolated RNA was determined spectrophotometrically and the integrity of the RNA was determined by gel electrophoresis. A total of $2 \mu \mathrm{g}$ of RNA was retro-transcribed to cDNA using the reverse transcription kit with the following primers:

GAPDH (forward, AGA ACA TCA TCC CTG CAT CC; reverse, CAC ATT GGG GGT AGG AAC AC), CXCR4 (forward, GGC TGT AGA GCG ATG TTT GC; reverse, GTA GAG GTT GAC AGT GTA CA), HIF-1 $\alpha$ (forward, GCA GCC AGA TCT CGG CGA AG; reverse, CTG TGT CCA GTT AGT TCA AAC TG); and Akt (forward, ATC GTC GCC AAG GAT GAG GT; reverse, TCT CGT GGT CCT GGT TGT AG) DNA was amplified with an initial denaturation at $94^{\circ} \mathrm{C}$ for $5 \mathrm{~min}$, followed by 35 reaction cycles $\left(94^{\circ} \mathrm{C}\right.$ for $1 \mathrm{~min}, 60^{\circ} \mathrm{C}$ for $2 \mathrm{~min}, 72^{\circ} \mathrm{C}$ for $1 \mathrm{~min}$ ) and by a final extension at $72^{\circ} \mathrm{C}$ for $10 \mathrm{~min}$. PCR products were analyzed by electrophoresis on $1.5 \%$ agarose gels.

\section{Western blot analysis}

Cells were harvested in RIPA lysis buffer supplemented with protease inhibitors. Lysates were separated by sodium dodecyl sulfate polyacrylamide gel electrophoresis and proteins were transferred to polyvinylidene difluoride membranes and blocked in TBS with Tween 20 (TBST) containing 5\% nonfat dry milk for $2 \mathrm{~h}$ at room temperature. Antibodies used and dilutions were as follows: monoclonal antiHIF-1 $\alpha$ (R\&D Systems, 1:1000), phospho-Akt (Cell Signaling, 1:1000), total Akt (Santa Cruz Biotechnology, 1:1000), CXCR4 (Santa Cruz Biotechnology, 1:250), anti $\beta$-actin (Abcam, 1:2000). After incubation in primary antibodies diluted in TBST with $5 \%$ nonfat dry milk at $4{ }^{\circ} \mathrm{C}$ overnight, membranes were exposed to the corresponding horseradish peroxidase-conjugated secondary antibodies and visualized by enhanced chemiluminescence.

\section{Plasmid construction and cell transfection}

The siRNA expression vector for HIF-1 $\alpha$ was constructed as described previously [26] (Aminova et al. 2005). The specific siRNA sequence targeting HIF-1 $\alpha$ was as follows: 5'-TGTGAGCTCACATCTTGAT-3'. 


\section{Cellular Physiology Cell Physiol Biochem 2015;36:1331-1345 \begin{tabular}{l|l} 
and Biochemistry Publisned onIIne: July U1, 2015 & $\begin{array}{l}\text { C 2015 S. Karger AG, Basel } \\
\text { www.karger.com/cpb }\end{array}$ \\
\hline
\end{tabular} \\ Sun et al.: Isoflurane Promotes Survival and Function of BMSCs}

Constructs were cloned into the pSuper-Retro vector (OligoEngine) under the control of polymerase-III H1RNA gene promoter. Cells were cultured as indicated and transfected using Lipofectamine 2000 (Invitrogen, Carlsbad, CA) according to the manufacturer's instructions.

\section{Immunohistochemistry}

Immunohistochemical detection of CXCR4 was performed in fixed BMSCs using an antibody against CXCR4 (Chemicon, 1:400), and nuclei were identified by 4,6-diamidino-2-phenylindole dihydrochloride (DAPI) staining.

Middle cerebral artery occlusion model

To generate the rat middle cerebral artery occlusion model (MCAo), rats were anesthetized with $10 \%$ $(\mathrm{w} / \mathrm{v})$ chloral hydrate at a dose of $3 \mathrm{ml} / \mathrm{kg}$ and the right arteries, including the common carotid artery (CCA), external carotid artery (ECA) and internal carotid artery, were isolated. The CCA and ECA were ligated at the proximal end with a bulldog clamp. A monofilament coated with polylysine was inserted into the CCA, the bulldog clamp was released and the monofilament was introduced until meeting slight resistance. Finally, the distal CCA was ligated and the skin was sutured.

\section{Behavioral tests}

A modified neurological severity score (mNSS) and foot fault tests were performed at 1, 7, and 14 days after MCAO as described previously [27]. Rats were divided into three groups: MCAO, in which rats were injected intravenously via the caudal vein with $0.2 \mathrm{ml}$ of phosphate-buffered saline (PBS) for control, MCAO+BMSC, in which rats were treated with a BMSC suspension $\left(2 \times 10^{6}\right.$ cells $)$ and MCAO+ISO/BMSC, in which rats were treated with BMSCs preconditioned with $2 \%$ isoflurane for $4 \mathrm{~h}$. Neurologic function was graded on a scale of 0 to 14 , where 0 is the normal score and 14 is the maximal deficit score. For locomotor assessment, mice were tested for placement dysfunction of forelimbs. The total number of steps used to cross the grid was counted and the total number of foot-faults was recorded. The results were expressed as the percentage of foot-faults to the total number of steps.

\section{Histology and immunohistochemistry}

Morphological changes in the ischemic brain were observed by staining with 2,3,5-triphenyltetrazolium chloride (TTC) of brain sections as described previously [28] (Zhao et al. 2012). Identification of BMSCs was performed by BrdU immunostaining and visualization by H\&E staining. In brain sections, the numbers of BrdU-positive BMSCs were counted at 400× magnification under an Olympus BH-2 microscope in the ipsilateral and contralateral hemispheres. PBS was used to replace primary antibodies as a negative control.

\section{Statistical analysis}

Results are expressed as the mean \pm SD unless otherwise specified. Differences were estimated using one-way analysis of variance (ANOVA) followed by a Student-Newman-Keuls test. P values $<0.05$ were considered statistically significant. Data analysis was performed using SPCC 17.0 statistical software.

\section{Results}

Characterization of BMSCS

BMSCs were expanded for 3 and 4 days after initial seeding (Fig. $1 \mathrm{~A}$ and B, respectively) and showed rapid expansion into colonies of confluent spindle-shaped cells. Matrix mineralization and fat droplet formation in cells cultured to passage 3 were visualized by Alizarin red S staining and Oil Red 0 staining (Fig. 1C and D, respectively). Cell surface antigen detection by flow cytometry showed that $96.7 \%$ of cells were positive for CD90 and $97.9 \%$ were positive for CD29, whereas $6.8 \%$ of cells reacted with the negative marker CD45, suggesting an almost pure population of BMSCs (Fig. 1E).

Time and dose dependent effects of isoflurane preconditioning on viability

To examine the effect of isoflurane on BMSC viability, cells were exposed to different doses of isoflurane for different times and cell viability was assessed by the MTT assay. The KARGER 
Fig. 1. Characterization of BMSCs. (A-B) Morphology of BMSCs incubated for 3 (A) and 4 days (B). (C) The mineralization nodes were monitored by Alizarin red S staining. (D) Fat droplet formation was monitored by Oil Red 0 staining. (E) Cell surface antigen detection showed that BMSCs were positive for CD90 (96.7\%) and CD29 (97.9\%), and negative for CD45 (6.8\%).

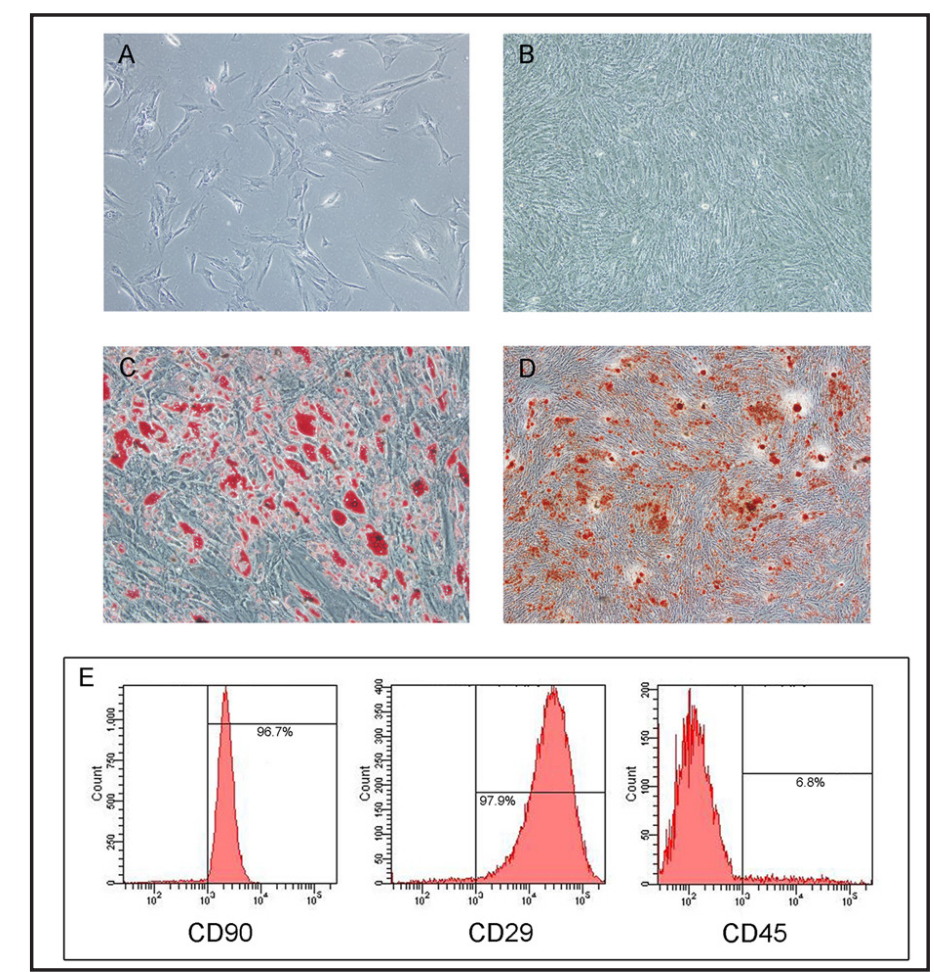

Fig. 2. Effect of isoflurane on BMSC viability. Cells were exposed to different concentrations of isoflurane for the indicated times. Growth inhibition was expressed as a percentage of the control (A). Flow cytometric analysis of Annexin $\mathrm{V}$ binding (abscissa) versus PI uptake (ordinate) in BMSCs treated with different concentrations isoflurane for $4 \mathrm{~h}$ (B) and with $2 \%$ isoflurane for 2, 4, 6, 12 and $24 \mathrm{~h}$ (C).

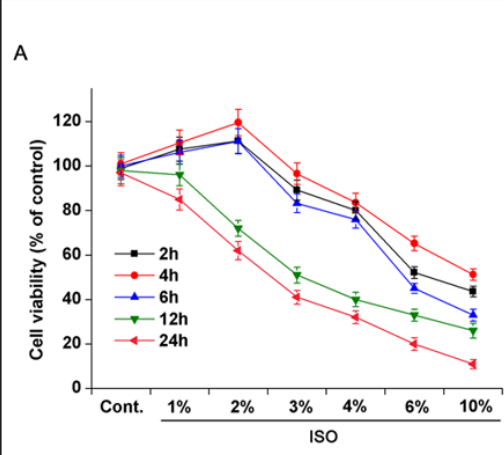

c

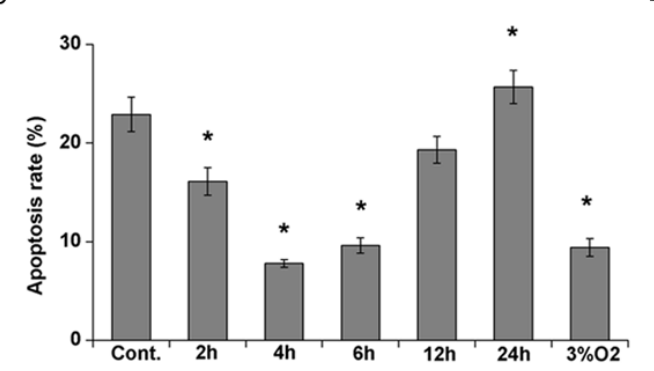

B

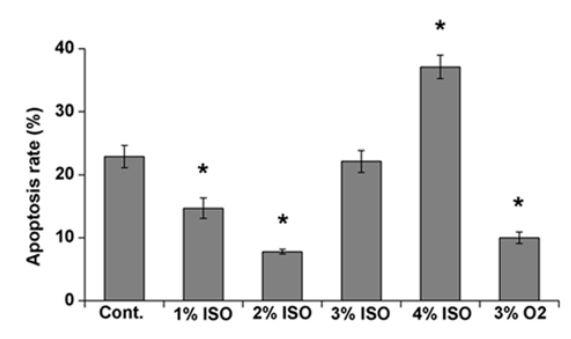

D

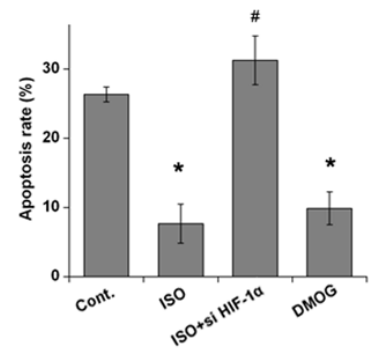

Percentage of apop-

totic cells was shown $\left({ }^{*} \mathrm{P}<0.05\right.$, vs. control). (D) Percentage of apoptotic cells in BMSCs exposed to $2 \%$ isoflurane in the presence or absence of si- HIF-1 $\alpha$ or DMOG (Cont. = untreated BMSCs, ISO = BMSCs treated with $2 \%$ isoflurane for $4 \mathrm{~h}$; ISO+si HIF-1 $\alpha=$ BMSCs treated with $2 \%$ isoflurane for $4 \mathrm{~h}$ and si-HIF-1 $\alpha$; DMOG $=$ dimethyloxalylglycine, hypoxia mimetics of HIF- $1 \alpha$ ). ( ${ }^{*} \mathrm{P}<0.05$ vs. control; \#P $<0.05$ vs. ISO). Each value represents the mean \pm SD of at least three independent experiments.

results showed that low doses and short treatment times increased the viability of BMSCs, whereas long exposure times $(>6 \mathrm{~h})$ and high doses $(>2 \%)$ decreased viability in a dosedependent manner (Fig. 2A). Annexin V/PI flow cytometric analysis showed that exposure to 
Fig. 3. Time dependent effect of isoflurane on BMSC migration. BMSCs were treated with $2 \%$ isoflurane for the indicated times and migration was assessed using Transwell chambers (A) Representative microscopic images of migrating BMSCs. (B) The number of migrating cells was counted in five fields for each condition and represents the average of three independent experiments ( ${ }^{*} \mathrm{P}<0.05$ vs. control).

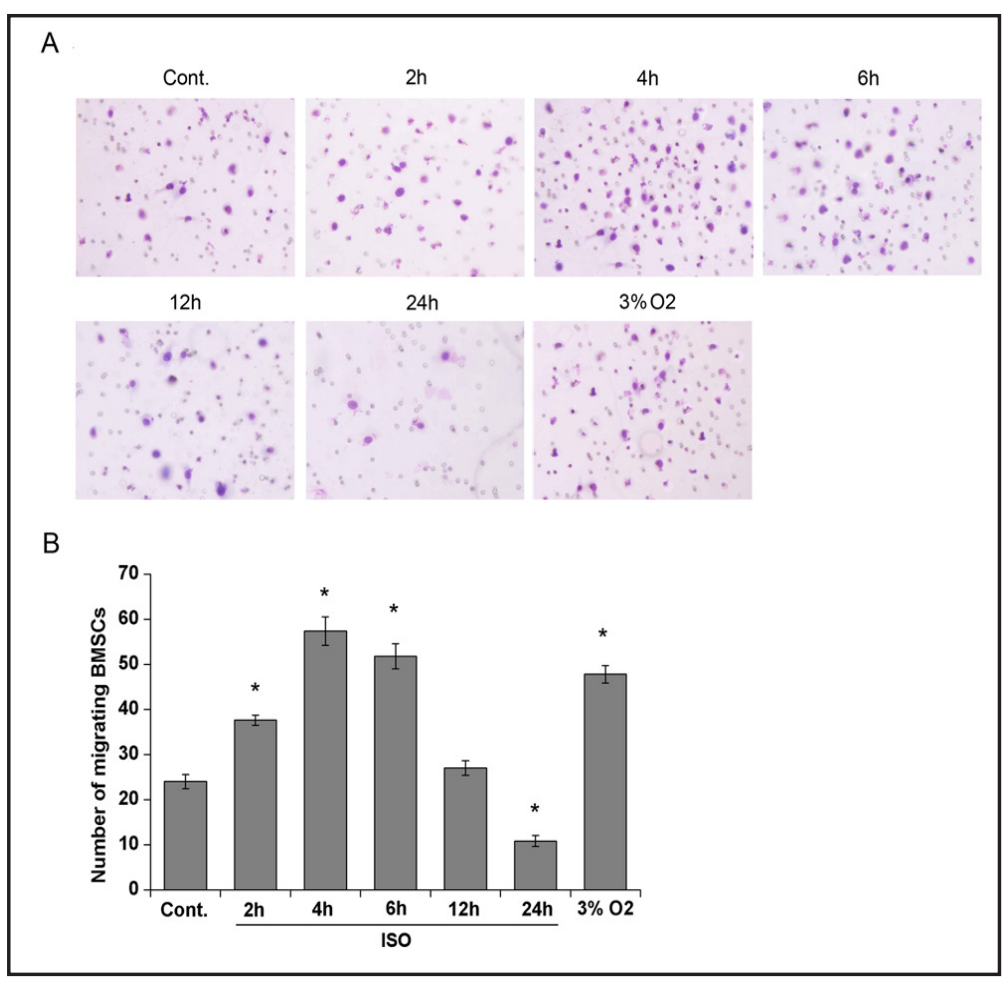

Fig. 4. Dose dependent effect of isoflurane on BMSC migration. BMSCs were treated with isoflurane at the indicated concentrations for 4 h. (A) Representative microscopic images of migrating BMSCs. (B) The number of migrating cells was counted in five fields for each condition and represents the average of three independent experiments ( ${ }^{*} \mathrm{P}$ $<0.05$ vs. control).
A

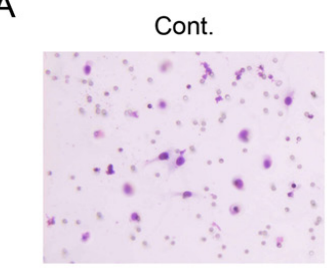

$3 \%$ ISO

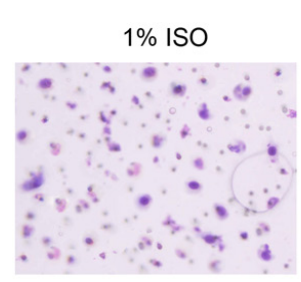

$4 \%$ ISO
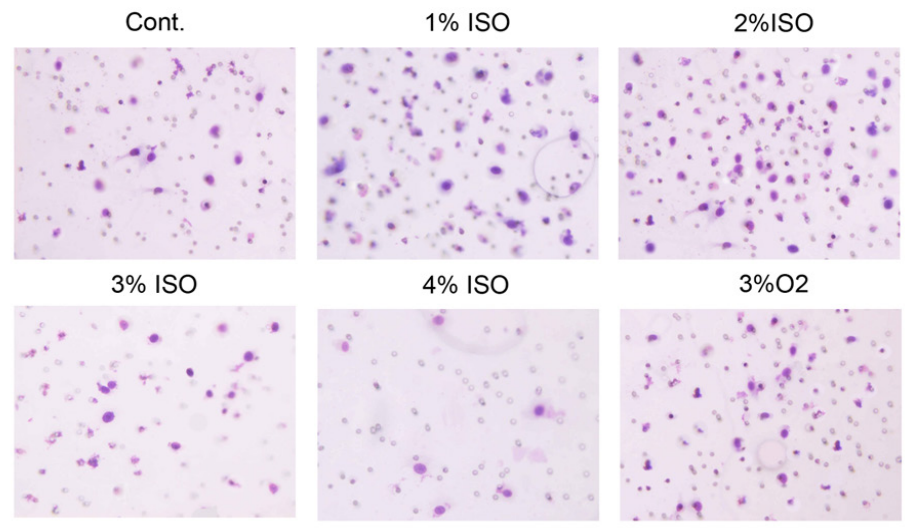

$3 \% \mathrm{O} 2$

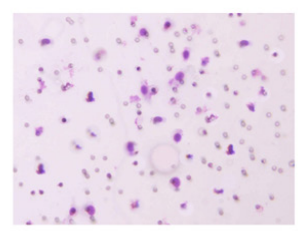

B

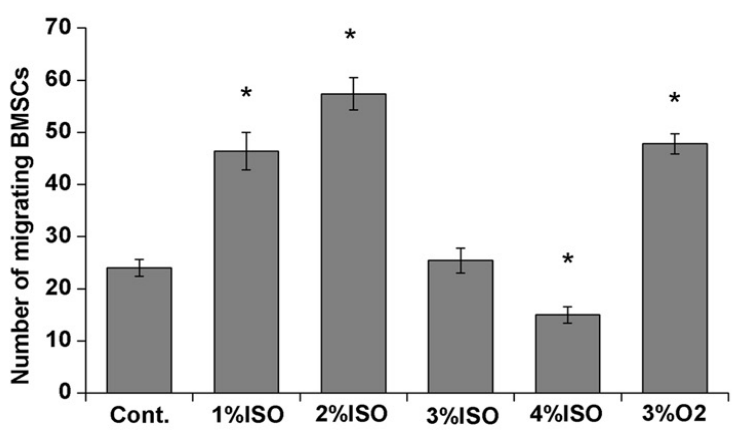

isoflurane at increasing doses for $4 \mathrm{~h}$ resulted in a significant reduction in the percentage of apoptotic cells at doses of $1 \%$ and $2 \%$ compared to the control $(\mathrm{P}<0.05)$, and this effect was mimicked by hypoxia, whereas isoflurane induced apoptosis at higher doses (Fig. 2B). Cells treated with $2 \%$ isoflurane for different times showed a significant progressive decrease in 


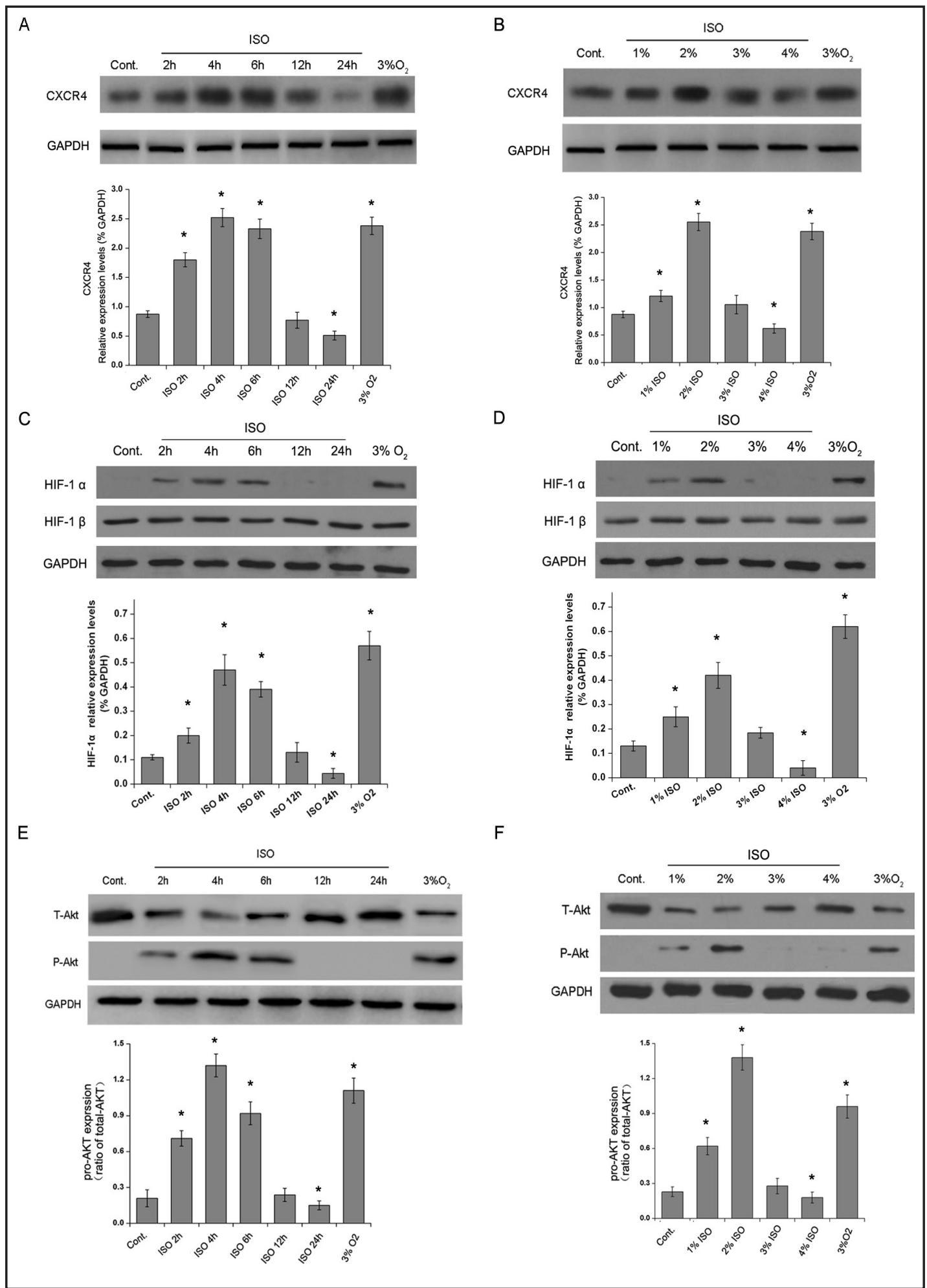

Fig. 5. Effect of isoflurane preconditioning on CXCR4, HIF-1 $\alpha$, and p-Akt/Akt expression in BMSCs. Western blot and RT-PCR analyses of CXCR4 protein and mRNA expression in BMSCs treated with isoflurane for the indicated times (A) and doses (B). Western blot and RT-PCR analyses of HIF- $1 \alpha$ and HIF-1 $\beta$ expression in BMSCs treated with isoflurane for the indicated times (C) and doses (D). Western blot and RT-PCR analyses of p-Akt/Akt protein and mRNA expression in BMSCs treated with isoflurane for the indicated times (E) and doses $(\mathrm{F})\left({ }^{*} \mathrm{P}<0.05\right.$ vs. control).

\section{KARGER}


A

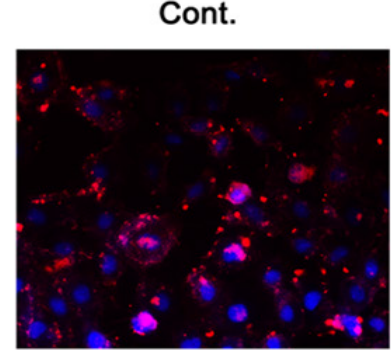

ISO+wort

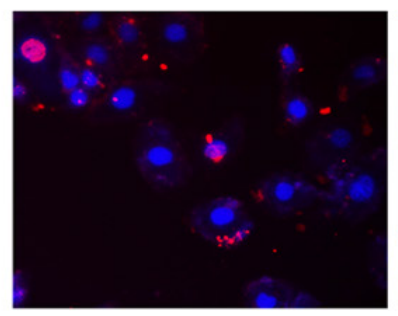

B

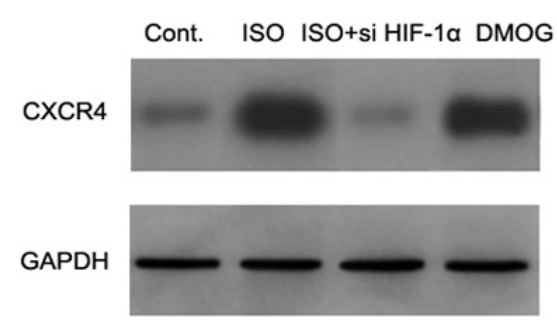

C

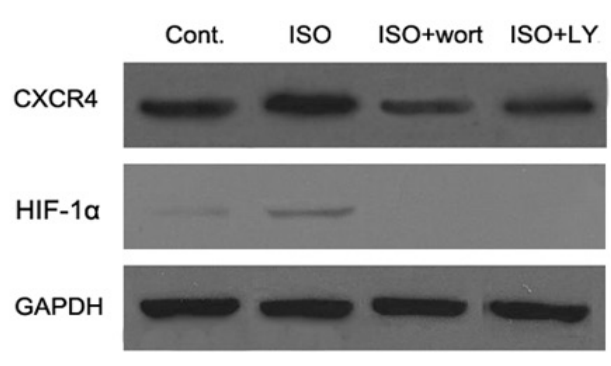

ISO

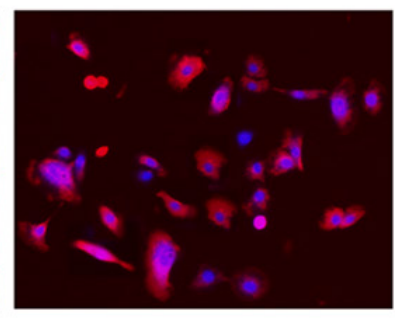

ISO+LY

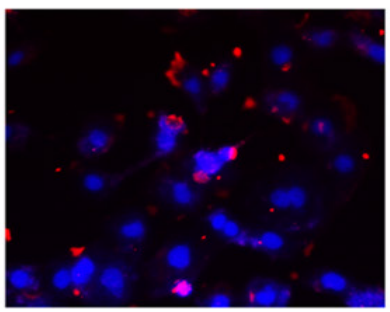

ISO+siHIF-1 $\alpha$

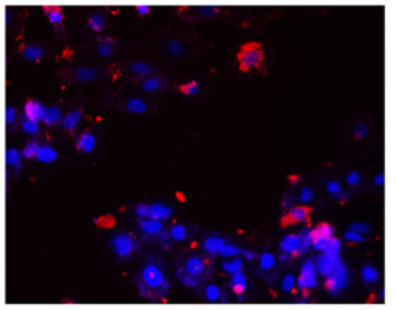

DMOG

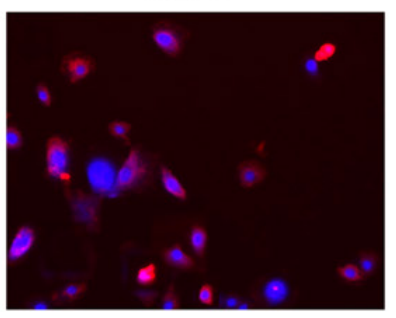

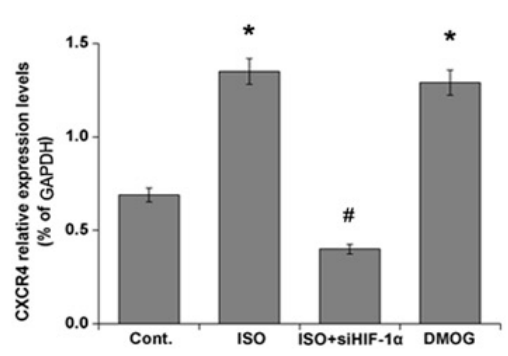

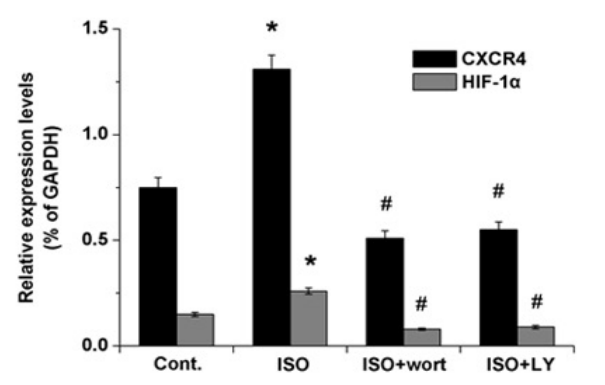

Fig. 6. Effect of the PI3K/Akt pathway and HIF-1 $\alpha$ on the expression of CXCR4 in BMSCs. (A) CXCR4 immunostaining in BMSCs treated as indicated (Cont. = untreated BMSCs, ISO = BMSCs treated with 2\% isoflurane for $4 \mathrm{~h}$; ISO+si HIF- $1 \alpha=$ BMSCs treated with $2 \%$ isoflurane for $4 \mathrm{~h}$ and si-HIF- $1 \alpha$; ISO+wort/LY= BMSCs treated with $2 \%$ isoflurane for $4 \mathrm{~h}$ followed by the PI3K/Akt inhibitors wortmannin or LY294002 for $2 \mathrm{~h}$; DMOG = dimethyloxalylglycine, hypoxia mimetics of HIF-1 $\alpha$ ). (B) Western blot and RT-PCR analyses of CXCR4 protein and mRNA expression in BMSCs treated with isoflurane or isoflurane + si-HIF- $1 \alpha\left({ }^{*} \mathrm{P}<0.05\right.$ vs. control; $\#$ P $<0.05$ vs. ISO). (C) Western blot and RT-PCR analysis of CXCR4 and HIF-1 $\alpha$ protein and mRNA expression in BMSCs treated with isoflurane or isoflurane + the PI3K/Akt inhibitors wortmannin or LY294002 ${ }^{*} \mathrm{P}<$ 0.05 vs. control; $\# \mathrm{P}<0.05$ vs. ISO).

apoptosis at 2 and $4 \mathrm{~h}$ similar to the effect of hypoxia $(\mathrm{P}<0.05)$, whereas longer exposures (6-24 h) increased the rate of BMSC apoptosis (Fig. 2C). Silencing of HIF-1 $\alpha$ abolished 
Fig. 7. Effect of HIF-1 $\alpha$ on BMSC migration. (A) BMSCs were treated as indicated (Cont. = untreated BMSCs, ISO = BMSCs treated with $2 \%$ isoflurane for $4 \mathrm{~h}$; ISO+si HIF- $1 \alpha=$ BMSCs treated with $2 \%$ isoflurane for $4 \mathrm{~h}$ and si-HIF- $1 \alpha$; DMOG = dimethyloxalylglycine, hypoxia mimetics of HIF$1 \alpha$ ) and migration was assessed using Transwell chambers (A) Representative microscopic images of migrating BMSCs. (B) The number of migrating cells was counted in five fields for each condition and represents the average of three independent experiments $(* \mathrm{P}<0.05$ vs. control; \#P $<0.05$ vs. ISO).

the isoflurane induced reduction in apoptosis, whereas the hypoxia mimetic dimethyloxalylglycine (DMOG), which stabilizes HIF- $1 \alpha$, had a similar effect than isoflurane, decreasing the number of apoptotic cells (Fig. 2D).

Time and dose dependent effect of isoflurane on BMSC migration

BMSCs were treated with $2 \%$ isoflurane for $2,4,6,12$, and $24 \mathrm{~h}$ or placed under conditions of hypoxia $\left(3 \% \mathrm{O}_{2}\right)$ for 24 $\mathrm{h}$, and cell migration was assessed using the Transwell assay. The results showed

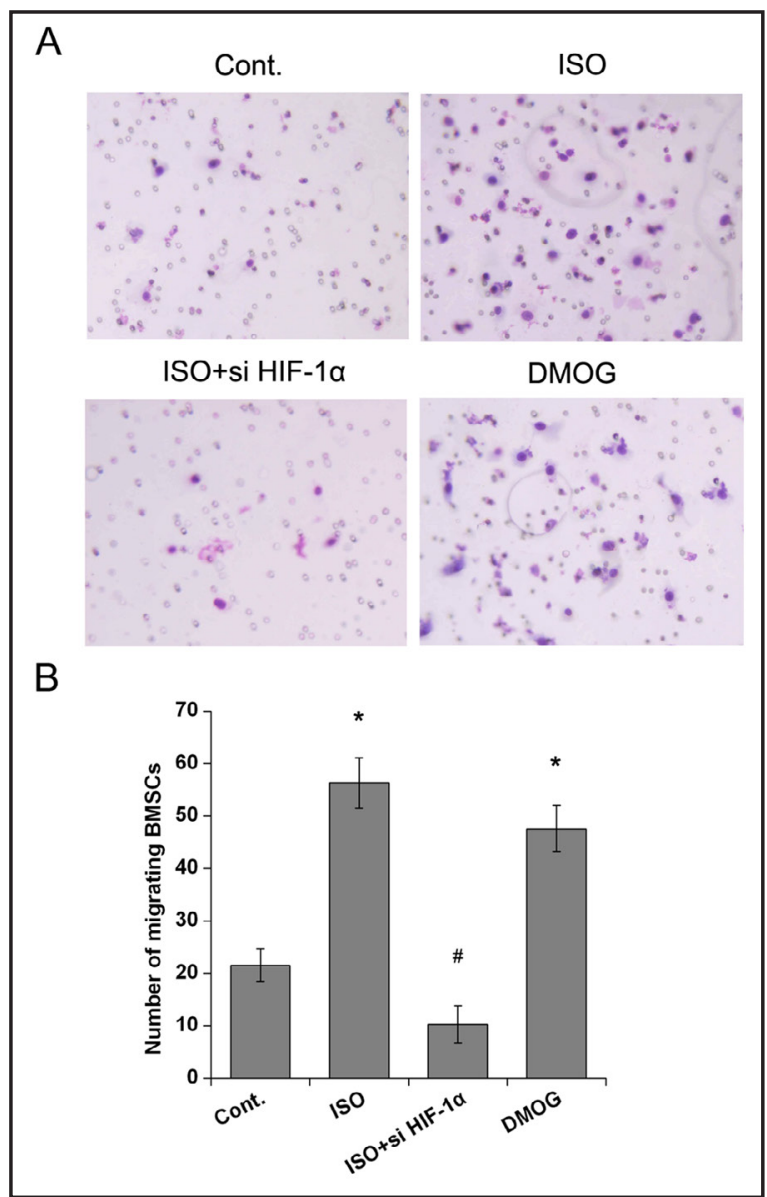

that the number of migrating BMSCs increased progressively up to $4 \mathrm{~h}$ of isoflurane exposure, whereas longer incubation times resulted in decreased cell migration (Fig. $3 \mathrm{~A}$ and B). Exposure of cells to hypoxia increased the number of migrating cells similar to the effect of low-dose isoflurane $(\mathrm{P}<0.05)$. Similar results were obtained when cells were exposed to increasing doses of isoflurane from $1 \%$ to $4 \%$, which showed that isoflurane dose-dependently significantly increased BMSC migration at low doses, similar to the effect of hypoxia, whereas high doses $(3 \%$ and $4 \%)$ inhibited BMSC migration $(\mathrm{P}<0.05)$ (Fig. $4 \mathrm{~A}$ and $\mathrm{B})$.

\section{Isoflurane preconditioning modulates CXCR4 expression and Akt activation}

To further explore the mechanisms underlying the effect of isoflurane on BMSC viability and migratory ability, we examined whether anesthetic preconditioning affected the expression of the SDF-1 receptor CXCR4, HIF- $1 \alpha$, HIF-1 $\beta$, and Akt signaling, which is known to regulate hypoxia-induced CXCR4 expression [24]. Western blot analysis showed that short time ( 2 and $4 \mathrm{~h}$ ) and low dose (1 and 2\%) isoflurane treatment upregulated the expression of CXCR4 in a time and dose dependent manner, whereas longer exposures and higher doses progressively restored CXCR4 expression and reduced it to below normal levels in BMSCs $(\mathrm{P}<0.05$ all, Fig. 5A and B). Hypoxia upregulated CXCR4 expression to a level similar to that observed in response to $2 \%$ isoflurane for $4 \mathrm{~h}$. A similar pattern was observed for HIF- $1 \alpha$ expression, which was upregulated by low isoflurane doses and short exposure times, as well as by hypoxia, whereas no effect of isoflurane on the expression of HIF-1 $\beta$ was observed ( $\mathrm{P}<0.05$ all, Fig. 5C and D). Similarly, Akt was activated by isoflurane at low doses and short exposure times. As shown in Fig. 5E and F, the relative levels of phospho-Akt increased significantly in a dose and time dependent manner up to $2 \%$ isoflurane and $2 \mathrm{~h}$ exposure, similar to the effect of hypoxia, whereas longer exposures or higher doses returned values to control levels ( $\mathrm{P}<0.05$ all, Fig. 5E and F). 


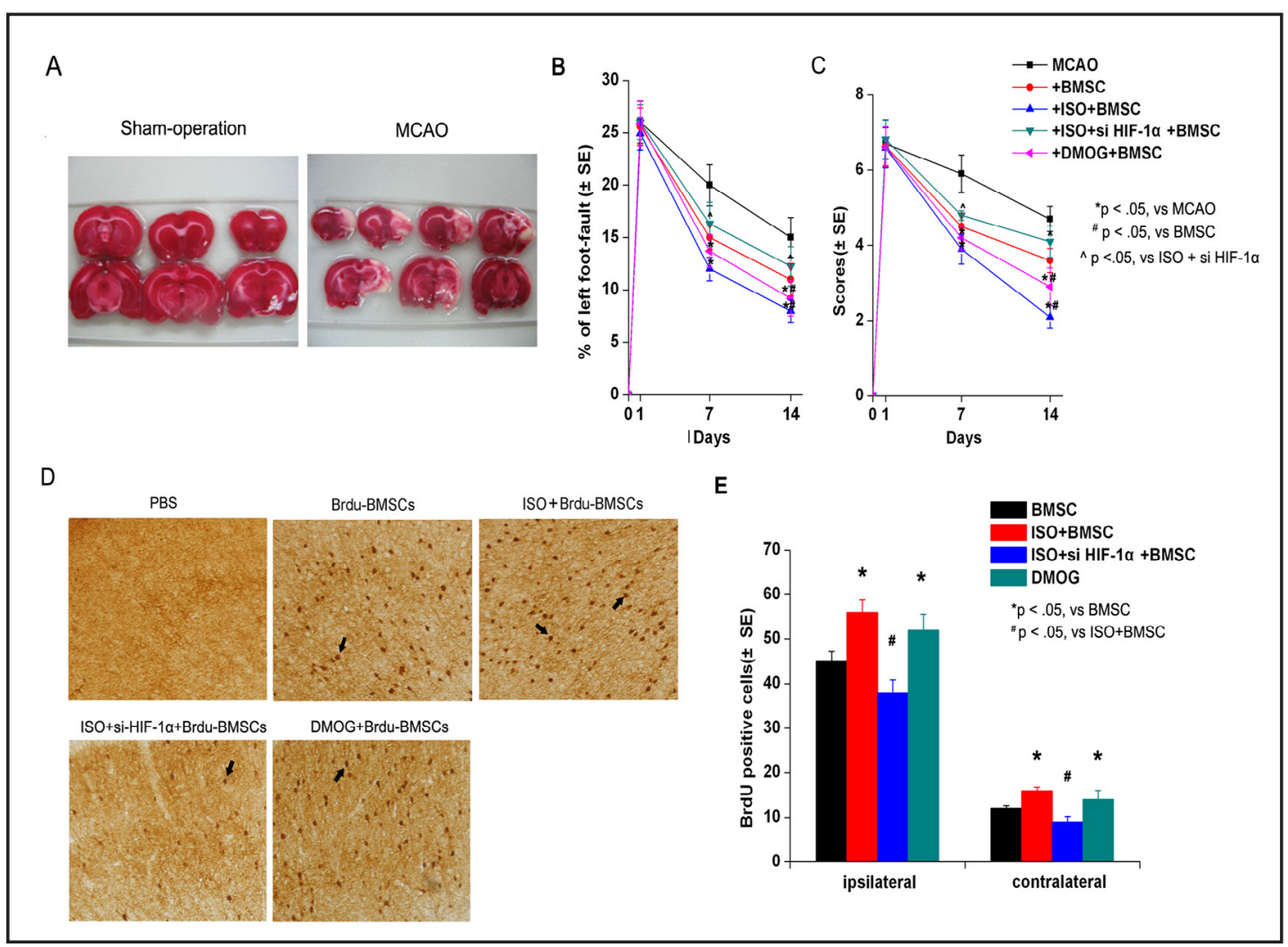

Fig. 8. ISO preconditioning improves BMSC engraftment into the ischemic brain and improves functional recovery in a mouse model of stroke. (A) Representative images of 3-TTC stained sections of the brains of sham operated and middle cerebral artery occlusion (MCAO) rats at $72 \mathrm{~h}$ post-surgery. (B-C) Results of the modified neurological severity score (B) and foot-fault test (C) at 7 and 14 days after MCAO in rats treated as indicated (Cont. $=$ untreated BMSCs, ISO = BMSCs treated with $2 \%$ isoflurane for $4 \mathrm{~h}$; ISO+si HIF- $1 \alpha=$ BMSCs treated with 2\% isoflurane for $4 \mathrm{~h}$ and si-HIF-1 $\alpha$; DMOG = dimethyloxalylglycine, hypoxia mimetics of HIF-1 $\alpha$ ). (D) Representative images of hematoxylin and eosin immunostaining for BrdU in BMSCs with or without ISO (2\%) pretreatment for $2 \mathrm{~h}$ and in the presence or absence of si-HIF-1 $\alpha$ or DMOG. Cells treated with PBS were used as the control. (E) Quantitative analysis of BrdU-immunoreactive BMSCs.

The isoflurane induced upregulation of CXCR4 in BMSCs is mediated by the modulation of HIF-1 $\alpha$ expression and Akt pathway activation

Because the effects of short exposure and low doses of isoflurane mimicked those of hypoxia, we examined whether HIF-1 $\alpha$ played a role in mediating the effect of isoflurane treatment in BMSCs. Immunocytochemical analysis of BMSCs using an antibody against CXCR4 showed that isoflurane increased the number of CXCR4 positive cells compared to the untreated controls, whereas siRNA mediated silencing of HIF-1 $\alpha$ abolished the effect of isoflurane on the expression of CXCR4 (Fig. 6A). Similarly, co-treatment of cells with the Akt inhibitors wortmannin or LY294002 resulted in a reduction in the number of CXCR4 positive cells, whereas treatment with DMOG increased the number of CXCR4 positive cells. These results were confirmed by RT-PCR and western blotting, which showed that isoflurane and DMOG upregulated CXCR4 at the mRNA and protein levels, whereas knockdown of HIF-1 $\alpha$ significantly abrogated the isoflurane-induced upregulation of CXCR4 $(\mathrm{P}<0.05$, Fig. 6B). Furthermore, pretreatment of cells with wortmannin or LY294002 abrogated the isofluraneinduced upregulation of CXCR4 and HIF- $1 \alpha$ in BMSCs at the mRNA and protein levels $(\mathrm{P}<$ 0.05 all, Fig. 6C). 


\section{Cellular Physiology Cell Physiol Biochem 2015;36:1331-1345 \begin{tabular}{ll|l} 
and Biochemistry Publisned onIIne: July U1, 2015 & $\begin{array}{l}\text { C) 2015 S. Karger AG, Basel } \\
\text { www.karger.com/cpb }\end{array}$ \\
\hline
\end{tabular} Sun et al.: Isoflurane Promotes Survival and Function of BMSCs}

Effect of HIF-1 $\alpha$ on BMSC migration

To determine the effect of HIF- $1 \alpha$ on isoflurane induced BMSC migration, cells were treated with $2 \%$ isoflurane for $4 \mathrm{~h}$ in the presence or absence of siRNA mediated HIF- $1 \alpha$ silencing or DMOG. The results showed that knockdown of HIF-1 $\alpha$ abrogated the isoflurane induced increase in BMSC migration, whereas the induction of hypoxia restored the high levels of BMSC migration (Fig. 7A and B).

Isoflurane preconditioning improves BMSC engraftment and functional recovery in a rat model of stroke

To examine the effects of isoflurane on brain function, we used a rat middle cerebral artery occlusion (MCAO) model to assess behavioral and morphological changes. Figure 8A shows representative images of 3-TTC stained brain sections of sham-operated and MCAO rats. The images show unilateral necrotic areas (white) in MCAO rat brains compared to the evenly stained (red) sections of sham-operated rats, indicating that the MCAO model was established successfully. To determine the effect of isoflurane on brain function in the stroke animal model, rats in the different groups were evaluated by the foot fault test and the modified neurological severity scores (mNSS) at 7 and 14 days after injection of BMSCs as described in the Materials and Methods section. The results showed that injection of BMSCs significantly improved brain function in the MCAO rat model, and isoflurane preconditioning further improved functional recovery in both tests on days 7 and 14 (Fig. $8 \mathrm{~B}$ and C). Knockdown of HIF-1 $\alpha$ reversed the effect of isoflurane whereas hypoxia (DMOG) enhanced the effect of BMSC treatment. To determine the effect of isoflurane preconditioning on the delivery of BMSCs into the ischemic brain, the number of BrdU stained cells in the ipsilateral and contralateral hemispheres was counted. The results showed that isoflurane pretreatment significantly improved BMSC engraftment in both hemispheres similar to the effect of DMOG, and this effect was abolished by HIF-1 $\alpha$ silencing (Fig. 8E). Figure 8D shows representative images of H\&E stained brain sections, with BrdU-positive BMSCs indicated by arrows.

\section{Discussion}

In the present study, we showed that isoflurane preconditioning improved the survival and migratory ability of BMSCs at low doses and during short exposure times, and these effects were mediated by the upregulation of HIF- $1 \alpha$ through the activation of PI3K/Akt signaling. Isoflurane upregulated CXCR4 via a mechanism dependent on HIF-1 $\alpha$ expression and PI3K/Akt signaling in vitro and promoted BMSC engraftment in the ischemic brain, as well as improving neurological function in a mouse model of stroke in vivo. Taken together, our results suggest that the protective effects of isoflurane are dose and time dependent and are mediated by the upregulation of CXCR4 in a HIF-1 $\alpha$ dependent manner through a mechanism involving the PI3K/Akt signaling pathway.

Volatile anesthetics can alter or modulate the expression of genes involved in cell survival in a specific time- and dose-dependent manner. Isoflurane induces the expression of $c$-jun and $c$-fos, which are the main components of the transcription factor AP-I complex and thus regulate several aspects of cell physiology in response to stress, in the heart, liver, kidney and brain [29]. Furthermore, isoflurane modulates nuclear factor- $\mathrm{kB}$ and Jun N-terminal kinase 1 expression in mice at low doses [30]. In the present study, isoflurane promoted survival at low doses and during short exposure times, whereas it induced cell death and inhibited the function of BMSCs at high doses and long exposure times. The dual effects of isoflurane were reported previously and explained by different mechanisms. Isoflurane was suggested to induce apoptosis by facilitating the release of calcium from the endoplasmic reticulum [31, 32]. However, a protective effect against apoptosis was demonstrated in rat hippocampus cultures [33], and isoflurane attenuated cytokine-induced cell death in vascular smooth muscle cells and human umbilical vascular endothelial cells [34]. Short 
exposure to isoflurane increases the levels of the antiapoptotic factor Bcl-2 in rats [14], whereas long exposure to isoflurane decreases Bcl-2 levels in cultured cells [2].

The sensing of anesthetic volatiles by mammalian cells can lead to phenotypic modifications that favor survival, similar to the sensing of oxygen [10]. Inhalational anesthetics such as isoflurane affect the expression of HIF-1 and HIF-1 responsive genes, which increases the resistance of cells to injury or stress. In the present study, we showed that isoflurane preconditioning upregulated HIF-1 $\alpha$ in a PI3K/Akt dependent manner in BMSCs. The upregulation of HIF-1 $\alpha$ by isoflurane was shown to have cardioprotective effects in several animal models $[13,35]$. Furthermore, in a rabbit model of myocardial ischemiareperfusion injury, the protective effect of isoflurane mediated by the upregulation of HIF- $1 \alpha$ was shown to involve the upstream PI3K/Akt/mTOR pathway [9]. In rat models of cerebral ischemia, isoflurane protects against ischemic neuronal injury through the induction of HIF$1 \alpha$ and iNos, and the involvement of the PI3K/Akt pathway in the neuroprotective effect of isoflurane via HIF-1 $\alpha$ upregulation was demonstrated in several studies [14, 36, 37]. However, few studies have evaluated the effect of inhalational volatiles on the function of MSCs. A recent study by Sun et al. showed that sevoflurane preconditioning enhanced the survival and migration of MSCs and improved the therapeutic potential of MSCs through the upregulation of HIF-1 $\alpha$ and p-Akt [38], which supports the results of the present study.

In the present study, the effect of isoflurane on promoting BMSC viability and migration, increasing CXCR4 levels and activating Akt was similar to the effect of hypoxia and was mediated by the upregulation of HIF- $1 \alpha$. Sub-lethal hypoxia exposure increases the tolerance and regenerative properties of many stem/progenitor cells [39-42], and cells preconditioned by hypoxia show increased survival after transplantation into the ischemic brain through the upregulation of HIF- $1 \alpha$, SDF- 1 and CXCR 4 among other factors [43]. Transplanted cells preconditioned by hypoxia show enhanced homing ability through the upregulation of CXCR4 [40, 41], and improve functional recovery in animal models of stroke [41, 44]. These studies support the present findings, which indicate that the protective effect of isoflurane is mediated by the upregulation of HIF- $1 \alpha$.

BMSCs have shown regenerative potential in models of myocardial, limb and brain ischemia, and when administered systemically, BMSCs migrate to the site of injury, promoting the regeneration of damaged tissues [17, 28, 45]. In the present study, we showed that isoflurane preconditioning upregulated the expression of CXCR4 via a mechanism dependent on HIF-1 $\alpha$ expression and the activity of the PI3K/Akt pathway. Furthermore, isoflurane increased the engraftment of BMSCs into the ischemic brain and improved functional recovery in a mouse model of stroke, and these effects were abrogated by HIF- $1 \alpha$ silencing. Taken together, our results suggested that the effect of isoflurane preconditioning on the survival and protective function of BMSCs was mediated by the upregulation of CXCR4 via a HIF-1 $\alpha$ dependent pathway. This finding is important because a significant challenge in the application of cell-based therapies is to improve the homing and engraftment efficiency of stem cells. SDF-1 and CXCR4 are important for the homing, chemotaxis, engraftment, and survival of different stem cells $[46,47]$. In a rat model of myocardial infarction, SDF-1 and CXCR4 were shown to mediate the migration of BMSCs towards the infarcted areas of the heart via activation of the PI3K/Akt pathway [48]. The interaction between SDF-1 and CXCR4 was shown to underlie the trafficking of transplanted MSCs to impaired sites in the brain in a rat model of left hypoglossal nerve injury [23]. Furthermore, BMSCs overexpressing CXCR4 migrate towards SDF1 $\alpha$, and injection of recombinant SDF1 $\alpha$ promotes the migration of BMSCs to the site of injection in the brain $[23,49]$. These findings indicate that the overexpresion of CXCR4 may be an effective strategy to improve the migration, survival and engraftment of BMSCs, underscoring the importance of our findings showing the effect of isoflurane preconditioning on the expression of CXCR4. Furthermore, these studies support the hypothesis that the mechanism underlying the protective effects of isoflurane in the brain may involve chemokine upregulation mediated by HIF-1 $\alpha$ expression and Akt activation, as shown in the present study. 


\section{Cellular Physiology Cell Physiol Biochem 2015;36:1331-1345

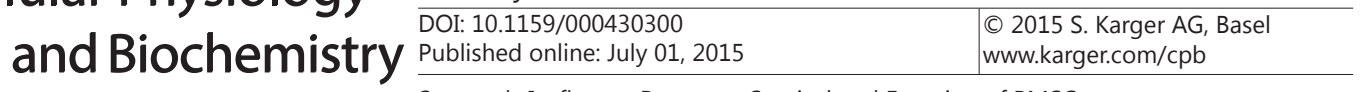 \\ Sun et al.: Isoflurane Promotes Survival and Function of BMSCs}

In conclusion, we showed that isoflurane preconditioning promotes the survival of BMSCs through the upregulation of HIF- $1 \alpha$ via the PI3K/Akt pathway, and its protective effects in the ischemic brain are mediated by the upregulation of CXCR4, leading to enhanced migratory ability and engraftment of BMSCs at sites of ischemia. Our findings suggest that isoflurane preconditioning at specific doses and exposure times enhances the neuroprotective effects of MSCs and could be a beneficial strategy to improve the efficiency of cell therapy.

\section{Disclosure Statement}

We declare that we have no conflicts of interest.

\section{Acknowledgments}

The study was supported by National Natural Science Foundation of China (Grant No 81201021).

\section{References}

1 Jun R, Gui-he Z, Xing-xing S, Hui Z, Li-xian X: Isoflurane enhances malignancy of head and neck squamous cell carcinoma cell lines: A preliminary study in vitro. Oral Oncol 2011;47:329-333.

-2 Wei H, Kang B, Wei W, Liang G, Meng QC, Li Y, Eckenhoff RG: Isoflurane and sevoflurane affect cell survival and bcl-2/bax ratio differently. Brain Res 2005;1037:139-147.

-3 Kvolik S, Glavas-Obrovac L, Bares V, Karner I: Effects of inhalation anesthetics halothane, sevoflurane, and isoflurane on human cell lines. Life Sci 2005;77:2369-2383.

4 Nikizad H, Yon JH, Carter LB, Jevtovic-Todorovic V: Early exposure to general anesthesia causes significant neuronal deletion in the developing rat brain. Ann N Y Acad Sci 2007;1122:69-82.

-5 Wang Q, Liang G, Yang H, Wang S, Eckenhoff MF, Wei H: The common inhaled anesthetic isoflurane increases aggregation of huntingtin and alters calcium homeostasis in a cell model of huntington's disease. Toxicol Appl Pharmacol 2011;250:291-298.

6 Jamnicki-Abegg M, Weihrauch D, Pagel PS, Kersten JR, Bosnjak ZJ, Warltier DC, Bienengraeber MW: Isoflurane inhibits cardiac myocyte apoptosis during oxidative and inflammatory stress by activating akt and enhancing bcl-2 expression. Anesthesiology 2005;103:1006-1014.

7 Wise-Faberowski L, Raizada MK, Sumners C: Oxygen and glucose deprivation-induced neuronal apoptosis is attenuated by halothane and isoflurane. Anesth Analg 2001;93:1281-1287.

8 Martini N, Preckel B, Thamer V, Schlack W: Can isoflurane mimic ischaemic preconditioning in isolated rat heart? Br J Anaesth 2001;86:269-271.

9 Raphael J, Zuo Z, Abedat S, Beeri R, Gozal Y: Isoflurane preconditioning decreases myocardial infarction in rabbits via up-regulation of hypoxia inducible factor 1 that is mediated by mammalian target of rapamycin. Anesthesiology 2008;108:415-425.

10 Zhao H, Iwasaki M, Yang J, Savage S, Ma D: Hypoxia-inducible factor-1: A possible link between inhalational anesthetics and tumor progression? Acta Anaesthesiol Taiwan 2014;52:70-76.

11 Sharp FR, Bernaudin M: Hif1 and oxygen sensing in the brain. Nat Rev Neurosci 2004;5:437-448.

12 Li QF, Wang XR, Yang YW, Su DS: Up-regulation of hypoxia inducible factor 1alpha by isoflurane in hep3b cells. Anesthesiology 2006;105:1211-1219.

-13 Hieber S, Huhn R, Hollmann MW, Weber NC, Preckel B: Hypoxia-inducible factor 1 and related gene products in anaesthetic-induced preconditioning. Eur J Anaesthesiol 2009;26:201-206.

14 Li QF, Zhu YS, Jiang H: Isoflurane preconditioning activates hif-1alpha, inos and erk1/2 and protects against oxygen-glucose deprivation neuronal injury. Brain Res 2008;1245:26-35.

15 Zhang L, Huang H, Cheng J, Liu J, Zhao H, Vizcaychipi MP, Ma D: Pre-treatment with isoflurane ameliorates renal ischemic-reperfusion injury in mice. Life Sci 2011;88:1102-1107. 


\section{Cellular Physiology Cell Physiol Biochem 2015;36:1331-1345 \begin{tabular}{ll|l} 
and BOI: 10.1159/000430300 & $\begin{array}{l}\text { (c) } 2015 \text { S. Karger AG, Basel } \\
\text { www.karger.com/cpb }\end{array}$ \\
\hline
\end{tabular}}

Sun et al.: Isoflurane Promotes Survival and Function of BMSCs

16 Sun Y, Li QF, Zhang Y, Hu R, Jiang H: Isoflurane preconditioning increases survival of rat skin randompattern flaps by induction of hif-1alpha expression. Cell Physiol Biochem 2013;31:579-591.

17 Chen J, Li Y, Wang L, Zhang Z, Lu D, Lu M, Chopp M: Therapeutic benefit of intravenous administration of bone marrow stromal cells after cerebral ischemia in rats. Stroke 2001;32:1005-1011.

18 Li Y, Chen J, Chen XG, Wang L, Gautam SC, Xu YX, Katakowski M, Zhang LJ, Lu M, Janakiraman N, Chopp M: Human marrow stromal cell therapy for stroke in rat: Neurotrophins and functional recovery. Neurology 2002;59:514-523.

19 Muller-Ehmsen J, Krausgrill B, Burst V, Schenk K, Neisen UC, Fries JW, Fleischmann BK, Hescheler J, Schwinger RH: Effective engraftment but poor mid-term persistence of mononuclear and mesenchymal bone marrow cells in acute and chronic rat myocardial infarction. J Mol Cell Cardiol 2006;41:876-884.

20 Kitaori T, Ito H, Schwarz EM, Tsutsumi R, Yoshitomi H, Oishi S, Nakano M, Fujii N, Nagasawa T, Nakamura T: Stromal cell-derived factor $1 /$ cxcr4 signaling is critical for the recruitment of mesenchymal stem cells to the fracture site during skeletal repair in a mouse model. Arthritis Rheum 2009;60:813-823.

21 Burger JA, Kipps TJ: Cxcr4: A key receptor in the crosstalk between tumor cells and their microenvironment. Blood 2006;107:1761-1767.

22 Ma J, Ge J, Zhang S, Sun A, Shen J, Chen L, Wang K, Zou Y: Time course of myocardial stromal cell-derived factor 1 expression and beneficial effects of intravenously administered bone marrow stem cells in rats with experimental myocardial infarction. Basic Res Cardiol 2005;100:217-223.

23 Ji JF, He BP, Dheen ST, Tay SS: Interactions of chemokines and chemokine receptors mediate the migration of mesenchymal stem cells to the impaired site in the brain after hypoglossal nerve injury. Stem Cells 2004;22:415-427.

24 Liu H, Xue W, Ge G, Luo X, Li Y, Xiang H, Ding X, Tian P, Tian X: Hypoxic preconditioning advances cxcr4 and cxcr7 expression by activating hif-1alpha in mscs. Biochem Biophys Res Commun 2010;401:509-515.

25 Kapinya KJ, Lowl D, Futterer C, Maurer M, Waschke KF, Isaev NK, Dirnagl U: Tolerance against ischemic neuronal injury can be induced by volatile anesthetics and is inducible no synthase dependent. Stroke 2002;33:1889-1898.

26 Aminova LR, Chavez JC, Lee J, Ryu H, Kung A, Lamanna JC, Ratan RR: Prosurvival and prodeath effects of hypoxia-inducible factor-1alpha stabilization in a murine hippocampal cell line. J Biol Chem 2005;280:3996-4003.

27 Chen J, Zhang C, Jiang H, Li Y, Zhang L, Robin A, Katakowski M, Lu M, Chopp M: Atorvastatin induction of vegf and bdnf promotes brain plasticity after stroke in mice. J Cereb Blood Flow Metab 2005;25:281-290.

28 Zhao Y, Guan Y, Xu Y, Li Y, Wu W: Sodium ferulate combined with bone marrow stromal cell treatment ameliorating rat brain ischemic injury after stroke. Brain Res 2012;1450:157-165.

29 Hamaya Y, Takeda T, Dohi S, Nakashima S, Nozawa Y: The effects of pentobarbital, isoflurane, and propofol on immediate-early gene expression in the vital organs of the rat. Anesth Analg 2000;90:1177-1183.

-30 Kadar B, Gombos K, Szele E, Ember I, Ivanyi JL, Csejtei R, Pajkos G: Effects of isoflurane on nfkappab p65, gadd45a and jnk1 expression in the vital organs of cba/ca mice. In Vivo 2011;25:241-244.

-31 Zhang G, Dong Y, Zhang B, Ichinose F, Wu X, Culley DJ, Crosby G, Tanzi RE, Xie Z: Isoflurane-induced caspase- 3 activation is dependent on cytosolic calcium and can be attenuated by memantine. J Neurosci 2008;28:4551-4560.

-32 Wei H, Liang G, Yang H, Wang Q, Hawkins B, Madesh M, Wang S, Eckenhoff RG: The common inhalational anesthetic isoflurane induces apoptosis via activation of inositol 1,4,5-trisphosphate receptors. Anesthesiology 2008;108:251-260.

-33 Gray JJ, Bickler PE, Fahlman CS, Zhan X, Schuyler JA: Isoflurane neuroprotection in hypoxic hippocampal slice cultures involves increases in intracellular ca2+ and mitogen-activated protein kinases. Anesthesiology 2005;102:606-615.

-34 de Klaver MJ, Manning L, Palmer LA, Rich GF: Isoflurane pretreatment inhibits cytokine-induced cell death in cultured rat smooth muscle cells and human endothelial cells. Anesthesiology 2002;97:24-32.

-35 Feng J, Lucchinetti E, Fischer G, Zhu M, Zaugg K, Schaub MC, Zaugg M: Cardiac remodelling hinders activation of cyclooxygenase-2, diminishing protection by delayed pharmacological preconditioning: Role of hif1 alpha and creb. Cardiovasc Res 2008;78:98-107.

-36 Zhou Y, Lekic T, Fathali N, Ostrowski RP, Martin RD, Tang J, Zhang JH: Isoflurane posttreatment reduces neonatal hypoxic-ischemic brain injury in rats by the sphingosine-1-phosphate/phosphatidylinositol-3kinase/akt pathway. Stroke 2010;41:1521-1527. 


\section{Cellular Physiology Cell Physiol Biochem 2015;36:1331-1345

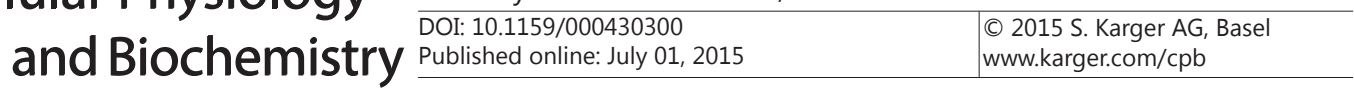 \\ Sun et al.: Isoflurane Promotes Survival and Function of BMSCs}

-37 Fang Li Q, Xu H, Sun Y, Hu R, Jiang H: Induction of inducible nitric oxide synthase by isoflurane postconditioning via hypoxia inducible factor-1alpha during tolerance against ischemic neuronal injury. Brain Res 2012;1451:1-9.

38 Sun X, Fang B, Zhao X, Zhang G, Ma H: Preconditioning of mesenchymal stem cells by sevoflurane to improve their therapeutic potential. PLoS One 2014;9:e90667.

-39 Yu SP, Wei Z, Wei L: Preconditioning strategy in stem cell transplantation therapy. Transl Stroke Res 2013;4:76-88.

40 Wei L, Fraser JL, Lu ZY, Hu X, Yu SP: Transplantation of hypoxia preconditioned bone marrow mesenchymal stem cells enhances angiogenesis and neurogenesis after cerebral ischemia in rats. Neurobiol Dis 2012;46:635-645.

-41 Wei N, Yu SP, Gu X, Taylor TM, Song D, Liu XF, Wei L: Delayed intranasal delivery of hypoxic-preconditioned bone marrow mesenchymal stem cells enhanced cell homing and therapeutic benefits after ischemic stroke in mice. Cell Transplant 2013;22:977-991.

42 Francis KR, Wei L: Human embryonic stem cell neural differentiation and enhanced cell survival promoted by hypoxic preconditioning. Cell Death Dis 2010;1:e22.

43 Theus MH, Wei L, Cui L, Francis K, Hu X, Keogh C, Yu SP: In vitro hypoxic preconditioning of embryonic stem cells as a strategy of promoting cell survival and functional benefits after transplantation into the ischemic rat brain. Exp Neurol 2008;210:656-670.

44 Hu X, Wei L, Taylor TM, Wei J, Zhou X, Wang JA, Yu SP: Hypoxic preconditioning enhances bone marrow mesenchymal stem cell migration via kv2.1 channel and fak activation. Am J Physiol Cell Physiol 2011;301:C362-372.

45 Dezawa M, Hoshino M, Nabeshima Y, Ide C: Marrow stromal cells: Implications in health and disease in the nervous system. Curr Mol Med 2005;5:723-732.

-46 Wojakowski W, Tendera M, Michalowska A, Majka M, Kucia M, Maslankiewicz K, Wyderka R, Ochala A, Ratajczak MZ: Mobilization of cd34/cxcr4+, cd34/cd117+, c-met+ stem cells, and mononuclear cells expressing early cardiac, muscle, and endothelial markers into peripheral blood in patients with acute myocardial infarction. Circulation 2004;110:3213-3220.

47 Yu X, Chen D, Zhang Y, Wu X, Huang Z, Zhou H, Zhang Z: Overexpression of cxcr4 in mesenchymal stem cells promotes migration, neuroprotection and angiogenesis in a rat model of stroke. J Neurol Sci 2012;316:141149.

-48 Yu J, Li M, Qu Z, Yan D, Li D, Ruan Q: Sdf-1/cxcr4-mediated migration of transplanted bone marrow stromal cells toward areas of heart myocardial infarction through activation of pi3k/akt. J Cardiovasc Pharmacol 2010;55:496-505.

49 Bhakta S, Hong P, Koc 0: The surface adhesion molecule cxcr4 stimulates mesenchymal stem cell migration to stromal cell-derived factor-1 in vitro but does not decrease apoptosis under serum deprivation. Cardiovasc Revasc Med 2006;7:19-24. 